\title{
Vietnam's Financial Liberalization and Its Correlative Mechanism with Economic Growth
}

\author{
Liujie Tang* \\ Economics School \\ Yunnan University of Finance and Economics \\ Kunming, China \\ yyw1101@163.com \\ Fan Ji \\ Economics School \\ Yunnan University of Finance and Economics
}

\author{
Kunming, China \\ 569896871@qq.com \\ Wenbo Li \\ Economics School \\ Yunnan University of Finance and Economics \\ Kunming, China \\ 916080085@qq.com
}

\begin{abstract}
To analyze and measure the degree of financial liberalization in Vietnam in the past 20 years, this paper quantifies the Vietnam's financial liberalization policies, uses the principal component analysis to measure its financial liberalization index. The regression result reflects a long-term and stable relationship between financial liberalization index and economic growth.
\end{abstract}

Keywords-financial liberalization index; economic growth; principal component analysis

\section{INTRODUCTION}

Under the background of multi-polarization and economic globalization, Vietnam has gradually strengthened the economic growth and trade cooperation, accelerated financial reforms and innovations, and expanded the financial openness to the world. The financial services has been more effective. Now, China's "One Belt and One Road" initiative is receiving widespread attention and recognition from the international community. Vietnam will join in China's "two corridors and one ring" to promote cooperation between the two countries. In the past 10 years, China's investment in Vietnam has increased by four times. In 2015, China-Vietnam bilateral trade volume reached $\$ 95.819$ billion, and the economic ties between China and Vietnam have become increasingly close.

In 2007, Vietnam joined the WTO and made a series of promises. As an economic pillar, finance has become the core of the modern economy and played a decisive role in the process of modernization. The financial liberalization index can reflect the current openness and the future direction of Vietnam's financial industry.

The implementation of financial liberalization policies in developing countries is the core content of the financial development theories proposed by McKinnon et al. in the 1970 s. The greatest contribution of the theory of financial deepening proposed by McKinnon and Shaw [1] is to advocate the reduction of excessive government finances intervention. Huang Jinlao [2] used eight simplified indicators to measure the degree of financial marketization in China, and graded the corresponding indicators. Each level was put a weight, and the financial liberalization degree in each country was calculated. Yi Wenfei and Ding Dan, extracted eight indexs that represent China's financial liberalization based on the theory of Huang Jinlao [3]. When Abiad et al. constructed the financial reform index and measured financial liberalization by several dimensions. Based on the institutional changes of China's financial system, the financial index was finally measured by seven indicators: 1) credit control and reserve requirements; 2) interest rate control; 3) barriers to entry; 4) state-owned bank; 5) capital account restrictions; 6) bank prudential supervision; 7) securities market reform policy [4]. The dimensions adopted by Abiad, Bandiera, and Huang Jinlao do not differ significantly. That is to say, the division of financial liberalization dimensions is determined in seven aspects.

The impact of financial liberalization on the economy has become an indispensable part of many scholars' studies. Bekaert, Chinn and Ito, and Edwards et al. believe that financial liberalization policies will have different impacts on economic growth, subject to the constraints of economic development stages in various countries. Silke Bumann et al. [5] found that financial liberalization has a positive impact on economic growth, while Abdullahi D. Ahmed [6] found opposite conclusions when he studied the south of sub-Sahara that financial liberalization had a negative impact on the economic growth of these countries.

\section{THE CURRENT FINANCIAL DEVELOPMENT OF VIETNAM}

In 1992, Vietnam implemented a series of reforms at the core of finance. In order to establish a diversified financial system, the banking system was adjusted to clarify the leading position of the central bank and supported by specialized banks in industry, agriculture, foreign trade and investment. The exchange rate policy was more flexible. The current financial development in Vietnam lies in banking, securities and insurance.

*Corresponding author 


\section{A. Banking}

The four state-owned banks in Vietnam dominate the banking industry. In the 1990s, the development of limited private banks was allowed. The banking industry expanded and its strength increased. By the end of 2014, 11 banks in Vietnam were listed as the world's top 1,000 banks. In 2015, the total assets of Vietnam's banking system were 7,300 trillion VND. The capital reached 578 trillion VND, an increase of $16.4 \%$ from 2014. The legal funds increased by $5.65 \%$ to 4,600 trillion VND. The minimum capital security ratio remains unchanged at $13 \%$.

While the economic reforms implemented in Vietnam have achieved remarkable results, there are also problems in the banking industry. The main problem is the unreasonable interest rates level. It has a negative impact on the lending behavior between state-owned enterprises and state-owned banks. It is not conducive to giving full play to banks' rational allocation of social resources. The inefficiency hinders the further deepening of Vietnam's financial marketization. Because state-owned commercial banks are an indispensable part of the financial system, their assets and loans account for more than $80 \%$ of the entire financial system, resulting in a high non-performing loan ratio, further increasing the risk of banks and inhibiting the development of the banking industry. In the future financial development, deepening the property rights reform and improving the efficiency of the banking industry are the priorities in the development of financial liberalization.

\section{B. Securities Market}

Compared with the banking industry, Vietnam's securities industry started relatively late. When it was first established, there were only two listed stocks. In 2016, more than 1,000 companies were listed on the Vietnam Stock Exchange. The total market value was equivalent to $65 \%$ of GDP. The total funds raised were as high as 2,000 trillion VND, which accounted for $23 \%$ of the total investment in the society. Since then, the Vietnamese securities market has gradually matured. Today, the market has attracted a large number of domestic and foreign investors to actively enter the market. The securities accounts number has increased from 3,000 in 2000 to 1.67 million in October 2016. Among them, overseas investors have opened 18,500 securities accounts in Vietnam. The investors are mainly from Japan, South Korea, Singapore, and the United States. The increase in foreign bank accounts has greatly promoted the introduction of foreign capital. At the same time, it has also helped to develop listed companies into worldrenowned brand enterprises and further promote Vietnam's economic image.

The development of the securities market is inseparable from the investors' behavior. At present, the investment market of the Vietnamese funds is not yet mature. Investors are lack of risk awareness. Therefore, strict market access approval has been made necessary and the implementation effect in practice is good. However, due to the effectiveness and marketization of the registration system, the eligibility criteria for promoters have declined. Therefore, in the future, the access of Vietnamese funds should reduce market access for funds [7].

The five-year plan (2016-2020) of Vietnam was formally launched in 2016. This year is of great significance for Vietnam. It is an important year for Vietnam to integrate into the ASEAN and join the Trans-Pacific Partnership Agreement. The securities market will play an important role.

\section{Insurance Market}

The current low level of insurance depth and density in Vietnam's insurance market determines that its development is still in its infancy. In 2013, the insurance depth is lower than the ASEAN average $(3.4 \%)$ by 2 percentage points, and the insurance density is lower than the ASEAN average (USD 132) of 109 dollars. The lower insurance coverage revealed the weak insurance awareness of the Vietnamese. The economic growth potential of Vietnam makes the lower level of the insurance market not seriously affect the people's living standards. Insurance demand will enter in a period of strong growth as the ageing population growing. During 2015 and 2025 , Vietnam's GDP growth rate is expected to remain at $6 \%$.

At present, there are still some problems that need to be solved in the Vietnam insurance market. First, the laws and regulations of Vietnam's domestic insurance are not perfect. Second, the anti-fraud related laws and regulations have not been enacted. Finally yet importantly, there are no specific provisions on the acquisition and closure of insurance companies. For these problems, Vietnam should continue to improve the legal system of the insurance market, establish relevant laws and regulations to ensure the stable operation of the insurance market strengthen risk prevention and avoid unnecessary losses [8].

\section{FINANCIAL LIBERALIZATION INDEX}

Financial liberalization is divided into six dimensions. The related liberalization policies are showed at Table1. Liberalization indicators are dummy variables. Cumulative values are used for the assignment of variables. Values are no longer limited to 0-1. Values are as follows: General events that represent financial liberalization or general policies and regulations are 0.25 or 0.5 . The important event is 1 , and the major policies and regulations are implemented as 1.5 or 2 . Depending on the degree of influence, the value assigned to multiple events or policies is allowed. Events or policies that oppose liberalization are given negative values.

TABLE I. 1993-2015 FinANCIAL LIBERALIZATION POLICY

\begin{tabular}{|c|c|}
\hline Index & Liberalization policy \\
\hline $\begin{array}{c}\text { Interest rate } \\
\text { control } \\
\left(X_{1}\right)\end{array}$ & $\begin{array}{l}\text { 1993-1995, Minimum deposit rate and maximum loan rate. } \\
\text { 1996-1999, loan interest rate cap. After 1997, the cap was } \\
\text { abolished. } \\
\text { Since 2000, The basic interest rate was introduced. The } \\
\text { basic interest rate ceiling is the percentage of the basic } \\
\text { interest rate. } \\
\text { Since } 2010 \text {, there is no ceiling on lending rates. } \\
\text { Since 2010, the implementation of the deposit interest rate } \\
\text { cap regulation has imposed a ceiling of } 5.5 \% \text { on short-term } \\
\text { deposits of 1-6 months and a floating interest rate on } \\
\text { longer-term deposit rates. } \\
2010 \text {, maintain } 9 \% \text { of the benchmark interest rate. } \\
2013 \text {, the Vietnam Development Bank funded } \\
\text { infrastructure and business development, provided interest- } \\
\text { rate support programs. } \\
2017 \text {, loan interest rate was cut by } 0.5 \% \text {. }\end{array}$ \\
\hline
\end{tabular}




\begin{tabular}{|c|c|c|c|c|c|c|}
\hline $\begin{array}{l}\text { Credit } \\
\text { control } \\
\left(X_{2}\right)\end{array}$ & \multirow{2}{*}{\multicolumn{6}{|c|}{ 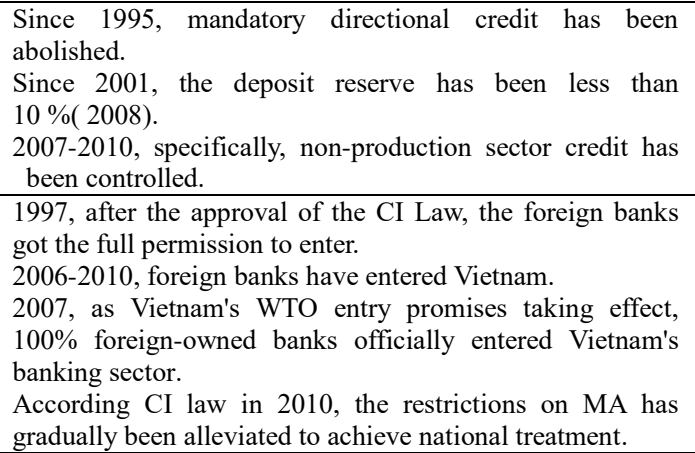 }} \\
\hline $\begin{array}{l}\text { Barriers to } \\
\text { Entry } \\
\left(X_{3}\right)\end{array}$ & & & & & & \\
\hline $\begin{array}{l}\text { Privatization } \\
\qquad\left(X_{4}\right)\end{array}$ & \multicolumn{6}{|c|}{$\begin{array}{l}2004-2010 \text {, Vietnam Foreign Trade Bank, Vietnam } \\
\text { Industrial and Commercial Bank had been privatized. } \\
\text { Since 2005, 1,472 state-owned enterprises have been } \\
\text { equalized, transferred, sold, and closed. } \\
\text { By the end of } 2006 \text {, about } 1,800 \text { enterprises have retained } \\
100 \% \text { of state-owned enterprises. They were reduced to } \\
1,500 \text { by the end of } 2007 \text {. Over the next few years, } 100 \% \text { of } \\
\text { state-owned enterprises will be further reduced and limited } \\
\text { to the national security sector and large enterprises. }\end{array}$} \\
\hline $\begin{array}{l}\text { Security } \\
\text { Market } \\
\left(X_{5}\right)\end{array}$ & \multicolumn{6}{|c|}{$\begin{array}{l}\text { 1997-1999, foreign participation was allowed with the } \\
\text { upper limit }(20 \%) \text {. } \\
2000 \text {, the stock market was brought into operation. } \\
2007 \text {, foreign holdings were up to } 30-49 \% \text {. } \\
2010 \text {, } 49 \% \text { listed and unlisted shares were held by } \\
\text { foreigners. }\end{array}$} \\
\hline $\begin{array}{l}\text { Foreign } \\
\text { exchange } \\
\quad\left(X_{6}\right)\end{array}$ & \multicolumn{6}{|c|}{$\begin{array}{l}2000-2010 \text {, the foreign exchange market had been formed. } \\
2001 \text {, procedures for opening foreign exchange accounts in } \\
\text { authorized foreign exchange banks and registering accounts } \\
\text { in national bank branches were enacted. } \\
2005 \text {, all remaining payment and transfer foreign exchange } \\
\text { limits for current account transactions have been } \\
\text { eliminated, and international current account transaction } \\
\text { rules that meet the International Monetary Fund's definition } \\
\text { have been specified. } \\
2011 \text {, Vietnam raised foreign exchange reserve rate. } \\
2014 \text {, VND intermediate exchange rate was cut by } 1 \% \text {. }\end{array}$} \\
\hline \multicolumn{7}{|c|}{$\begin{array}{l}\text { Source: WTO official website https://www.wto.org/; Economic and C } \\
\text { Office of the Chinese Embassy in Vietnam http://vn.mofcom.gov.cn/ }\end{array}$} \\
\hline \multicolumn{7}{|c|}{ The subjective allocation of the policies is shown in Table } \\
\hline \multicolumn{7}{|c|}{ TABLE II. QUANTIZED DATA } \\
\hline Year & $\mathbf{X}_{1}$ & $\mathbf{X}_{2}$ & $\mathbf{X}_{3}$ & $X_{4}$ & $\mathbf{X}_{5}$ & $\mathbf{X}_{6}$ \\
\hline 1993 & 0.5 & 0.25 & 0.25 & 7 & & 0 \\
\hline 1994 & & 0.25 & & U & & 0 \\
\hline 1995 & 5 & 1 & 0.25 & 0 & 0 & 0 \\
\hline 1996 & 75 & 1 & 0 & 0 & 5 & 0 \\
\hline 1997 & 0.75 & 1 & 0.5 & 0 & .25 & 0 \\
\hline 1998 & 1 & 1 & S & 0 & 25 & 0 \\
\hline 1999 & 1 & 1 & 0.5 & 0 & 0.5 & 0 \\
\hline 2000 & 1.5 & 1 & 0.5 & 0 & 1 & 1 \\
\hline 2001 & 1.5 & 1.5 & 0.5 & 0 & 1 & 1.25 \\
\hline 2002 & 2 & 1. & 0 & 0 & 1 & 1.25 \\
\hline 200 & 2 & 1. & & U & 1 & 1.25 \\
\hline 2004 & 2 & 1. & 0.5 & 1 & 1 & 1.25 \\
\hline 2005 & 2 & 1.5 & 0.5 & 1 & 1 & 1.75 \\
\hline 2006 & 2 & 1.5 & 2 & 1.5 & 1 & 1.75 \\
\hline 2007 & 2 & 2.5 & 2.25 & 2 & 1.5 & 1.75 \\
\hline 2008 & 2 & 2 & 2.5 & 2 & 1.5 & 1.75 \\
\hline 2009 & 2 & 2.5 & 2.75 & 3 & 1.5 & 1.75 \\
\hline 2010 & 3.75 & 2.25 & 3 & 3 & 1.75 & 1.75 \\
\hline 2011 & 3.75 & 2.25 & 3 & 3 & 1.75 & 2 \\
\hline 2012 & 3.75 & 2.25 & 3 & 3 & 1.75 & 2 \\
\hline 2013 & 3.75 & 2.25 & 3 & 3 & 1.75 & 2 \\
\hline
\end{tabular}

\begin{tabular}{|c|c|c|c|c|c|c|}
\hline 2014 & 4 & 2.25 & 3 & 3 & 1.75 & 2.25 \\
\hline 2015 & 4 & 2.25 & 3 & 3 & 1.75 & 2.25 \\
\hline
\end{tabular}
Source of data: Report "Strengthening the Financial System Capacity of Vietnam and Completing
the Financial Liberalization Under the GATS Framework" (Table 8)

In order to quantify the financial liberalization degree of Vietnam, it is necessary to process data and perform principal component analysis (PCA). From the correlation matrix (Table 3), it can be seen that there is a high degree of correlation between variables, indicating that the information overlaps, so it is necessary to extract the principal component (PC) as the main explanatory variable for analysis.

The number of PCs is mainly judged by eigenvalues, because the eigenvalues can used to reflect the influence of the principal component index. The principal component corresponding eigenvalues greater than 1 are the first $\mathrm{m}$ principal components, indicating that the principal components can explain other ingredients. It can be seen from the variance decomposition analysis that the eigenvalue of the first component is greater than 1. The variance explains about $90.5 \%$ information, so the first component is analyzed as PC (Table 4).

TABLE III. TABLE 3 CORRELATION MATRIX

\begin{tabular}{|l|l|l|l|l|r|r|}
\hline & \multicolumn{1}{|c|}{$\mathbf{X}_{\mathbf{1}}$} & \multicolumn{1}{|c|}{$\mathbf{X}_{\mathbf{2}}$} & $\mathbf{X}_{\mathbf{3}}$ & $\mathbf{X}_{\mathbf{4}}$ & $\mathbf{X}_{\mathbf{5}}$ & $\mathbf{X}_{\mathbf{6}}$ \\
\hline $\mathbf{X}_{\mathbf{1}}$ & 1 & 0.835 & 0.867 & 0.881 & 0.920 & 0.886 \\
\hline $\mathbf{X}_{\mathbf{2}}$ & 0.835 & 1 & 0.872 & 0.876 & 0.929 & 0.885 \\
\hline $\mathbf{X}_{\mathbf{3}}$ & 0.867 & 0.872 & 1 & 0.975 & 0.874 & 0.816 \\
\hline $\mathbf{X}_{\mathbf{4}}$ & 0.881 & 0.876 & 0.975 & 1 & 0.873 & 0.836 \\
\hline $\mathbf{X}_{\mathbf{5}}$ & 0.920 & 0.929 & 0.874 & 0.873 & 1 & 0.956 \\
\hline $\mathbf{X}_{\mathbf{6}}$ & 0.886 & 0.885 & 0.816 & 0.836 & 0.956 & 1 \\
\hline
\end{tabular}

TABLE IV. TOTAL VARIANCE EXPLAINED

\begin{tabular}{|c|c|c|c|c|c|c|}
\hline Component & \multicolumn{3}{|c|}{ Initial Eigenvalue } & \multicolumn{3}{c|}{ Extract square and loadings } \\
\hline 1 & Total & $\begin{array}{c}\% \text { of } \\
\text { Variance }\end{array}$ & $\begin{array}{c}\text { Cumulative } \\
\%\end{array}$ & Total & $\begin{array}{c}\% \text { of } \\
\text { Variance }\end{array}$ & $\begin{array}{c}\text { Cumulative } \\
\%\end{array}$ \\
\hline 2 & 5.428 & 90.464 & 90.464 & 5.428 & 90.464 & 90.464 \\
\hline 3 & 0.279 & 4.643 & 95.107 & - & - & - \\
\hline 4 & 0.165 & 2.758 & 97.865 & - & - & - \\
\hline 5 & 0.075 & 1.246 & 99.112 & - & - & - \\
\hline 6 & 0.036 & 0.604 & 99.716 & - & - & - \\
\hline 7 & 0.017 & 0.284 & 100.00 & - & - & - \\
\hline
\end{tabular}

TABLE V. COMPONENT MAtrix

\begin{tabular}{|c|c|}
\hline \multirow{2}{*}{ Component } & composition \\
\cline { 2 - 3 } & 1 \\
\hline Interest & 0.944 \\
\hline $\begin{array}{c}\text { Credit } \\
\text { control }\end{array}$ & 0.946 \\
\hline $\begin{array}{c}\text { Barriers to } \\
\text { Entry }\end{array}$ & 0.947 \\
\hline Privatization & 0.953 \\
\hline $\begin{array}{c}\text { Security } \\
\text { Market }\end{array}$ & 0.973 \\
\hline $\begin{array}{c}\text { Foreign } \\
\text { exchange }\end{array}$ & 0.943 \\
\hline
\end{tabular}

According to the component matrix (Table 5), the principal component loading is divided by the square root of the eigenvalue to derive the coefficient FLI between the principal component and each factor, i.e. financial liberalization. The formula is: 


$$
F L I=0.405 X_{1}+0.406 X_{2}+0.406 X_{3}+0.409 X_{4}+0.418 X_{5}
$$
$+0.405 X_{6}$

Substituting the data in the quantized data table into the above linear combination gives the following table:

TABLE VI. FLI

\begin{tabular}{|c|c|c|c|c|c|c|c|}
\hline Year & $\boldsymbol{F L I}$ & Year & $\boldsymbol{F L I}$ & Year & $\boldsymbol{F L I}$ & Year & $\boldsymbol{F L I}$ \\
\hline 1993 & 0.4055 & 1999 & 1.223 & 2005 & 3.15775 & 2011 & 6.41875 \\
\hline 1994 & 0.4055 & 2000 & 2.0395 & 2006 & 3.97125 & 2012 & 6.41875 \\
\hline 1995 & 0.71 & 2001 & 2.34375 & 2007 & 4.89225 & 2013 & 6.41875 \\
\hline 1996 & 0.81125 & 2002 & 2.54625 & 2008 & 4.79075 & 2014 & 6.62125 \\
\hline 1997 & 1.01725 & 2003 & 2.54625 & 2009 & 5.50425 & 2015 & 6.62125 \\
\hline 1998 & 1.1185 & 2004 & 2.95525 & 2010 & 6.3175 & -- & -- \\
\hline
\end{tabular}

\section{FINANCIAL LIBERALIZATION INDEX AND ECONOMIC} GROWTH

Taking Vietnam's actual GDP from 1993 to 2015 as an explanatory variable, the financial liberalization index FLI is an explanatory variable.

\section{A. Processing data and verifying data for stationarity}

The logarithmization of the explanatory variable RGDP and the explanatory variable FLI was performed to obtain the LNRGDP sequence and the LNFLI sequence, respectively, and the two time series were tested for stationarity.

According to the test results (Table 7), the actual GDP sequence is an unstable sequence, and t-test thresholds are all greater than the critical values at the levels of $1 \%, 5 \%$, and $10 \%$. Therefore, the assumption of the unit root cannot be rejected. The sequence is non-stationary. The stationary sequence is obtained after the first-order difference of the original sequence. The t-test threshold is -2.996274 , which is less than the critical value at the levels of $1 \%, 5 \%$, and $10 \%$. There is an assumption that the unit root can be rejected. Therefore, the LNRGDP sequence is first-order single integer. Similarly, we can see that the financial liberalization index LNFLI is a first-order single integer sequence.

TABLE VII. ADF TEST RESUlTS (1993-2015)

\begin{tabular}{|l|l|l|l|l|}
\hline Variables & LNRGDP & LNFLI & $\triangle$ LNRGDP & $\triangle$ LNFLI \\
\hline ADF test value & 1.8602 & -2.579 & -9.2963 & -4.5697 \\
\hline 1\% Significant level & -3.8086 & -3.7696 & -3.8315 & -3.788 \\
\hline 5\% Significant level & -3.0207 & -3.0049 & -3.03 & -3.0124 \\
\hline 10\% Significant level & -2.6504 & -2.6422 & -2.6552 & -2.6461 \\
\hline stationarity & No & No & Yes & Yes \\
\hline
\end{tabular}

\section{B. Co-integration test}

The co-integration test was performed on the two first-order single integer sequences, and it was determined that there was no long-term stable relationship between the two variables. Regressing $\triangle$ LNRGDP and $\triangle$ LNFLI to establish the cointegration relationship between real GDP and financial liberalization index from 1993 to 2015 , and obtain regression results as follows:

$$
\begin{aligned}
& L N G D P_{T}= 4.66+0.44 L N F L I_{T} \\
&(0.017) \\
& N=23 \quad(0.030) \\
& R^{2}=0.910
\end{aligned}
$$

The residuals of the regression use the stationarity test. The results are shown in Table 8.The Prob is small, and the ADF test value of residual is less than the critical value at each level of significance. Therefore, the assumption that there is a unit root can be rejected, indicating that the residual sequence is stable. It can be verified that there is a long-term stable relationship between LNRGDP and LNFLI.

TABLE VIII. RESIDUAL TEST RESULTS

\begin{tabular}{|l|l|l|l|}
\hline Variables & ADF test value & Prob & Critical value \\
\hline resid & -1.788854 & 0.0705 & $-2.674290(1 \%)$ \\
\cline { 3 - 4 } & & & $-1.957204(5 \%)$ \\
\cline { 3 - 4 } & & & $-1.608175(10 \%)$ \\
\hline stationary & \multicolumn{3}{|c|}{ Yes (Significant level) } \\
\hline
\end{tabular}

\section{CONCLUSIONS}

This paper uses the data from 1993 to 2015 to measure Vietnam's financial liberalization index and conducts empirical research on economic growth. Combined with the current financial development status in Vietnam, the following conclusions are obtained:

The financial liberalization index in Vietnam shows that Vietnam's financial liberalization has shown a significant upward trend. The financial liberalization index increased from approximately 0.4055 in 1993 to 4.89225 in 2007, an increase of approximately 11 times from 4.797905 in 2008 to 6.62125 in 2015. The growth rate was $38 \%$. Prior to joining the WTO, Vietnam's financial liberalization accelerated, economic growth accelerated, and the overall national strength further improved. This made it possible to join the WTO in 2007. Since then, Vietnam's financial liberalization process has slowed, but it still shows growth. In the study of the linkage mechanism between financial liberalization and economic growth in Vietnam, it shows that the actual GDP represents the economic growth index. There is a co-integration relationship between the financial liberalization index and economic growth, that is, there is a long-term and stable relationship. From the regression equation, it can be seen that the financial liberalization index has changed by $1 \%$ as a whole, and the leading role in economic growth has increased by $0.44 \%$. This has reached a level where financial development has had a positive impact on the economy.

Based on the above conclusions, it can be seen that the level of liberalization of Vietnam's financial industry has been increasing and it has gradually integrated into the process of world economic integration. Financial liberalization is beneficial to the development of bilateral trade between China and Vietnam. In 2014, Vietnam joined the Asian Infrastructure Investment Bank and promoted the interconnection between China and Vietnam. In the context of the One Belt and One Road, the bilateral trade level between China and Vietnam will be further strengthened. Vietnam's economic development will be faster.

\section{ACKNOWLEDGMENT}

This paper is supported by the Key Scientific Research Foundation of Education Bureau of Yunnan Province, China 
(Grant No. 2015Z131).Thanks are due to the reviewer for valuable discussion.

\section{REFERENCES}

[1] Shi Qian. "Review of the financial deepening theory of McKinnon and Xiao." Knowledge Economy, 2011 (19): 37-37. (In Chinese)

[2] Huang Jinlao. "Optimal Arrangement of Financial Liberalization." International Finance Research, 2002 (1): 26-32. (In Chinese)

[3] Yi Wenfei, Ding Dan. "Design and Analysis of China's Financial Liberalization Index. Economic Science,” 2007 (3): 66-75. (In Chinese)

[4] Abiad A, Detragiache E, Tressel T. "A new database of financial reforms.” IMF Staff Papers, 2010, 57(2): 281-302.
[5] Bumann S, Hermes N, Lensink R." Financial liberalization and economic growth: A meta-analysis." Journal of International Money and Finance, 2013, 33: 255-281.

[6] Ahmed A D. "Effects of financial liberalization on financial market development and economic performance of the SSA region: An empirical assessment. Economic Modelling." 2013, 30: 261-273.

[7] Qiu Qiuhe, He Anni. "Discussion on the Development Strategy of Vietnam Securities Investment Fund Industry Based on Foreign Experience.” Research on Regional Finance, 2011,(12):55-59 (In Chinese)

[8] Tang Jincheng, Chen Liyong. "Research on the Development of Insurance Market in Vietnam.” Southeast Asia, 2012 (10): 48-54. (In Chinese) 